\title{
STRATEGY IN DEVELOPMENT OF PROCESSING SALAK AT UD. SALACCA THROUGH BUSINESS MODEL CANVAS APPROACH
}

\author{
Juni Hartati ${ }^{1}$; Yulia Windi Tanjung ${ }^{1)}$; Anugrah Sri Widiasyih"1); Timbul Rasoki ${ }^{2}$; \\ 1) Program of Agribusiness, Faculty of Agriculture, Universitas Graha Nusantara \\ ${ }^{2)}$ Program of Agribusiness, Faculty of Science and Technology, Universitas Terbuka \\ Email: ${ }^{1}$ juni.hartatibatubara@gmail.com; ${ }^{2}$ timbulrasoki@ecampus.ut.ac.id
}

\section{How to Cite :}

Hartati, J., YW Tanjung, AS Widiasyih, T Rasoki, 2019. Strategy in Development of Procesing Salak at UD. Salacca Through Business Model Canvas Approach. Journal of Agri Socio-Economics and Business. 1 (1): 1-14. DOI: https://doi.org/10.31186/jaseb.1.2.1-14

ARTICLE HISTORY

Received [ 2019-11-14]

Revised [2019-11-21]

Accepted [2019-11-27]

\section{KEYWORDS}

BMC, Salak, SWOT

This is an open access article under the $C C-B Y-S A$ license

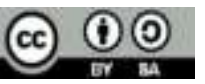

\section{ABSTRACT}

This study is aimed to analyze business model, internal external environment and formulate alternative strategies in UD. Salacca based on Business Model Canvas. The methods of research used are descriptive qualitative method. The data was obtained through secondary data and primary data. Data collected through depth interviews, observation and focus group discussion. The sampling method used was purposive sampling. Data were analyzed using the SWOT and BMC. The results showed that SWOT has Strengths (S), South Tapanuli is the salak production center in North Sumatra. Weaknesses (W) such as some products are not always available and cannot meet large-scale demand or exports; venture capital, technology and labor are still limited; there is no official cooperation contract with suppliers, customers and distributors. Therefore, BMC now needs to be improved by utilizing Opportunities $(\mathrm{O})$ including the assistance from the Government in the form of counseling, training and mentoring of the production machinery business; product promotion facilities at trade shows / festivals and also trade sites; other than that the product has been in demand by domestic and foreign tourists; The business already has a link to export products. So as to be able to face the Threat (T) of many competing products that use substitute raw materials and more sophisticated production technology resulting in consumers not loyal. The resulting alternative strategies are increasing consumer reach and business scale; improvement of production facilities and infrastructure; improving services with consumers; partnerships with distributors and souvenir vendors; increase capital, technology and labor. 


\section{INTRODUCTION}

The Agricultural sector plays a strategic role in the development of the Indonesian economy. Most people depend on agriculture, plantations, fisheries, livestock, which are the main food sources both in the form of fresh and processed. In Indonesia, there are various types of agricultural commodities that can be further processed into high-quality and high-value products, one of which is snake fruit. Zalacca is an agricultural product and is classified as a horticultural crop that has good prospects to be cultivated. South Tapanuli Regency is a salacca-producing center in North Sumatra, a type of salak Sidimpuan (Salacca sumatrana Becc). West Angkola District is the largest zalacca planting area and the highest amount of salak production compared to other districts in South Tapanuli Regency. Zalacca as a local potential, including plants that do not contain high risk, but still requires intensive care and care so that the fruit produced is of good quality. Zalacca are available all the time, but at the same time the price becomes equal low and often happens not to be harvested because operational and distribution costs are not comparable with a very low sale value. This effort is in line with government policies that are developing superior agricultural products through agro-industry. Agriculture will be able to be a savior if it is seen as a system related to industry and services. If agriculture stops only as an onfarm activity (agribusiness), the added value is small. Agricultural value added can be increased through downstream activities (off farm agribusiness), in the form of agroindustry and agricultural services (Soekartawi, 2010).

UD Salacca is one of the business units engaged in processing food and beverages made from raw salak such as dodol, chips, syrup, dates and others. On its business journey, UD Salacca, which was established in 2014, faces increasingly dynamic business competition. At present the type of processing business has increasingly developed, especially zalacca. The growth and development of new businesses of the same type makes UD Salacca required to innovate business and develop the best strategies in the short and long term in order to win the competition between similar products or other product substitutions. In addition, a strategy is still needed so that this business can withstand changes in various economic conditions and increasingly fierce business competition. To be able to compete in intense competition, companies need and need to prepare a business model innovation strategy as a strategy to win the competition by developing innovative value propositions, market segmentation and key partners which are the absolute key factors in global market competition (Peratasari and Dewanto, 2013). One business model that can capture change and combine it with a novelty is the Business Model Canvas (BMC) (Ostewalder, 2015; Dinudin et al, 2015). This study aims to analyze the business model, strengths, weaknesses, opportunities, threats (SWOT) and formulate an alternative strategy for UD Salacca based on BMC (Amanulla et al, 2015). Through this research, it is expected to be a source of information and input for agro-industry entrepreneurs and for policy makers as a reference for general agro-industry development strategies.

\section{RESEARCH METHODS \\ Method of Collecting Data}

This research is planned to be conducted at UD Salacca, located in the village of Parsambat, West Angkola District, South Tapanuli Regency, North Sumatra. The type of data used in this study includes primary data and secondary data. Primary data 
obtained through in-depth interviews and Focus Group Discussion (FGD) to the company and direct observation in the field. Whereas secondary data was obtained through literature, journals, previous research, books, internet, and related agencies such as the Regional Government, the Central Statistics Agency, and the Agriculture Service, as well as the Trade and Industry Office.

Data collection techniques carried out by interview, FGD, observation, and literature study. Interviews were conducted in depth (indepth interview) with semistructured which means the interviewer had prepared the questions asked himself but did not rule out the possibility of additional new questions. FGDs are conducted to strengthen business development ideas that are synergized from various fields in the company. Then the field observations were made to support research data and information. The technique of taking respondents in this study was done by purposive sampling, which is the technique of determining respondents with certain considerations suitable for use in qualitative research. Therefore, respondents are key informants who know the most information needed in this study. Respondents can be selected based on their respective capacities / expertise both within the company including; owner / owner, production and marketing employees, and in the company externals including; government, suppliers (farmer partners), and customers.

The analytical method used in this research is descriptive qualitative analysis. The initial stages in this descriptive analysis are based on the Business Model Canvas to describe how UD Salacca is currently doing business. The next stage is to identify SWOT in the internal and external environments that affect the company. The internal environment is analyzed through 9 components in BMC, while the external environment through the environmental analysis of the business model consists of four sources, namely market analysis, industrial strength, key trends, and macroeconomic strength. Each component of the business model environment has different factors. Factors that influence market analysis include market issues, market segments, needs and demands, switching costs, and the attractiveness of revenue. After the SWOT identification process of various components in BMC, the data from the identification results will be input and consideration for formulating the strategy through the SWOT analysis matrix at UD Salacca. The link between SWOT Analysis and BMC starts from mapping the results of the strategies produced by the SWOT analysis into the BMC component. From this it can be seen which components have changed due to a new strategy. This mapping can later produce more than one strategy that can be used as an alternative. But then it is necessary to analyze the strengths and weaknesses of each of the alternative strategies produced so that the strategies to be applied are appropriate and appropriate in the development of salak agroindustry at UD Salacca.

\section{RESULTS AND DISCUSSION}

\section{Profile Of UD. Salacca}

UD. Salacca is one of the business units engaged in the salak fruit processing industry which was founded in 2014. UD. Salacca is located on Sibolga street Km. 11 Parsangkan-Aek Nabara, Angkola District, South Tapanuli. In 2008 it started with an Agrina cooperative initiated by a farmer group in the West Angkola District to start research and development of salacca processed products as a solution for farmers during the main harvest and as a solution that increases the age of product resilience. 
But after 2012 UD. Salacca separated itself from the agrina cooperative and formed a new business called the salacca trade business. At the beginning of the UD business. Salacca produces 4 types of products, namely salak chips, dodol salak, salak syrup and date palm. As consumer demand for products that are more innovative and varied, UD. Salacca adds a variety of new products, namely zalacca agar, zalacca coffee beans, zalacca soy sauce, softdrink zalacca and zalacca honey. UD. Salacca has 4 Workers in the Family and 10 Workers Outside the Family. The main raw material for the product is red salak (salak narara), South Tapanuli, North Sumatra, which has a characteristic flesh whose fruit is dominated by red color, sweet taste, acid, high water content and larger fruit with different salak in general. The main supplier of raw materials is South Tapanuli zalacca farmers. UD. Salacca already has a certification from BPOM RI and MUI halal certificate. UD. Salacca also accepts internship students from the economics faculty of Graha Nusantara University. UD. Salacca also got an achievement, namely the Charter award at the peak of the Al-Ahmadi Award in Sumatra in 2015 as a finalist in the category of SMEs in the field of innovative agri business and zalacca bean coffee received an award from the Minister of Agriculture as the bestvasivation product in 2016. Product marketing methods carried out by UD. Salacca is by directly opening its own shop by serving local and foreign buyers and in collaboration with distributors to supply products to consumers.

\section{Internal and External Environment Analysis}

\section{Internal Environment Analysis}

Internal environmental analysis in this study was carried out through 9 components of the BMC in order to see the existence of good and proper integration between its components. The analysis in the order of each component is as follows:

\section{a. Customer Segment}

UD. Salacca has a demographic based customer segment that is all types of ages, all religions due to halal products, all types of work because of affordable prices. Geographically, it is specifically for South Tapanuli regional customers, both domestic and foreign customers, but it does not exclude the possibility of ordering outside the region. The psychographic aspect of the UD product. Salacca for customers who have a lifestyle like unique and innovative products as well as customers who like snacks or souvenirs from the region.

\section{b. Value Propositions}

This component describes the combination of products and services that create value for specific customer segments. Value offered by UD. Salacca for its customers by offering a variety of salak processed products that are diverse and each has a taste and uniqueness that is not found in other regions. UD. Salacca has the value of product quality standards facilitated by the South Tapanuli Industry and Trade Office (Disperindag), Halal MUI certification, and passed the BPOM RI certification. UD. Salacca also packaging / packaging products that are hygienic, modern and practical according to consumer needs. Zalacca raw materials used are salak with good quality.

\section{c. Channels}

This component describes how a company communicates with its customer segments and reaches them to provide a value proposition. The channels owned by 
UD. Salacca including promotions have been carried out through various social media such as Instagram and Facebook. UD. Salacca also has a marketing channel by working with distributors or permanent resellers in the City of Padang Sidimpuan as well as travel agents who bring tourists to stop by to buy souvenir products at UD outlets. Salacca.

\section{d. Customer Relationships}

This component describes the customer relationships that the company builds with specific customer segments. UD.Salacca in establishing relationships with customers using personal service relationships intended for certain customers who are considered important. Customers who come directly to the outlet are usually given information about product details and may sample the product before buying. For regular customers UD. Salacca offers products via mobile phones and then products are delivered to their destination.

\section{e. Arus Revenue Streams}

Source of income UD. Salacca comes from selling 9 kinds of products. The biggest income comes from salak chips and salak dodol products as superior products. The companys revenue streams that often occur repeatedly income streams, because some customers have the loyalty of the product to make purchases repeatedly. However, there are also some customers who only make one purchase. The pricing mechanism applied by the company is based on the cost of production and also the minimum profit to be obtained. The selling price will be negotiated with prospective customers prior to the signing of the contract for permanent customers. Sales of UD products. Salacca experiences ups and downs every month, the biggest sales occur during major holidays but for normal days sales continue to run with standard profits.

\section{f. Key Resources}

The main resource in a business model will explain the important assets needed in the business for a business model to function. UD. Salacca\&\#39;s main resource is raw material for salak. South Tapanuli is the Salak Production center in North Sumatra. Other main resources, namely Human Resources (HR), are as many as 10 Outside Family Workers (TKLK) and 4 Workers in the Family (TKDK) who handle the process of salak production. This is because most of the production process still uses manual methods, especially in stripping zalacca skin, slicing zalacca meat and handling equipment and production machinery still requires employee supervision. Other main resources in the form of machinery, factory facilities, and buildings are considered very important in the implementation of production. While the implementation of production will also greatly affect the products produced. If the machine or building facilities have problems, it will greatly hamper the production process so that it will affect the completion time of customer orders.

\section{g. A Key Activity}

Key activities will relate to the main resources of the company. For processing the production of products, UD. Salacca has HR who have high creativity so as to create a variety of innovative and unique processed products. Production activities are carried out in permanent buildings strategically located close to customers and close to raw materials. The supply of salak raw materials is close to the farmers\&\#39; zalacca 
plantations. Outlet / store locations are also close to the causeway making it easier to market products. While marketing activities are carried out through promotion on social media and business relations owned by companies and assisted by Connectors for tourists.

\section{h. Business Partnerships (Key Partnerships)}

This component describes the partnership run by UD. Salacca UD. Salacca has a partnership with suppliers to meet the needs of production materials including: a) farmers, b) distributors, souvenir traders and d) travel agents. Partner farmers are salak farmers in the South Tapanuli area. While distributors are free (not bound) only do sales transactions to UD. Salacca Traders of souvenirs buy certain quantities of goods to be sold at their respective outlets while still using the trademark of UD. Salacca Travel agents work together by suggesting tourists to stop by to buy souvenirs.

\section{i. Cost Structure}

This cost structure component describes the costs that must be incurred in running a business. The largest expenditure for sequential companies is for the purchase of salak, purchase of production goods and payment of salaries for TKLK and TKDK. After the nine components of the business model from UD. Salacca, then the next step is to map it to a picture or commonly referred to as \&quot;canvas\&quot;. Mapping the elements in each component will make it easier to summarize the overall picture of business activities that are currently running. The BMC mapping on UD Salacca can be seen in picture 1 .

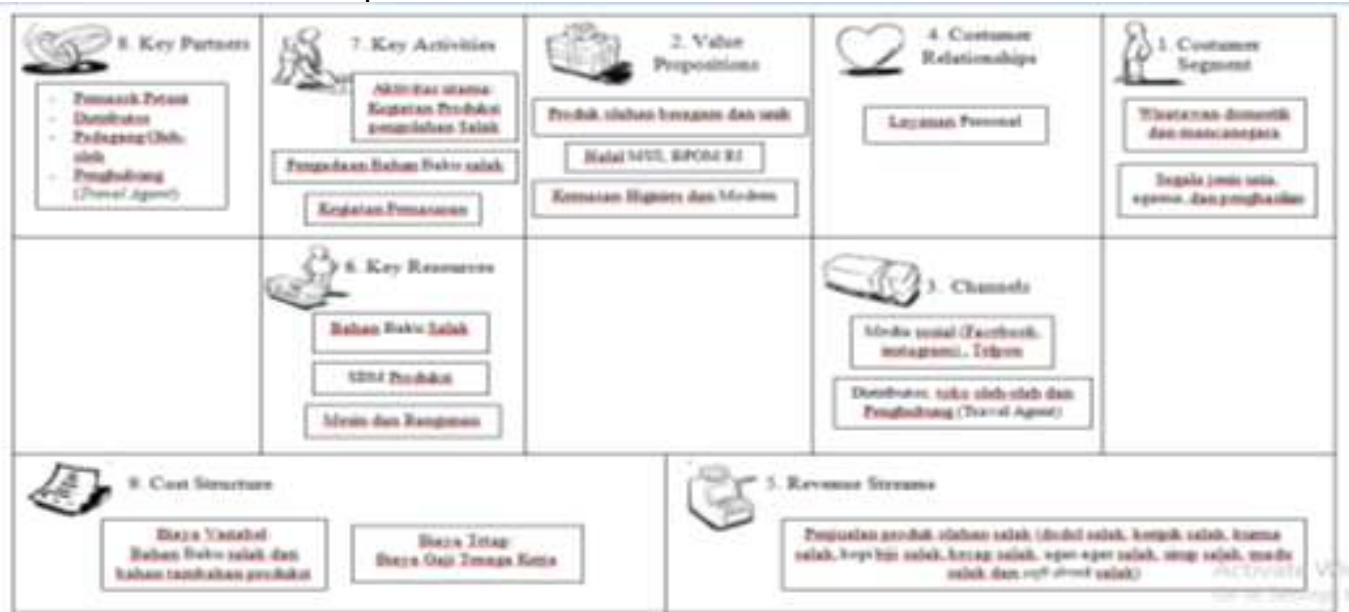

Picture 1. Business Canvas Model of UD. Salacca

\section{Analysis of the External Environment}

\section{a. Market Analysis}

Market analysis is carried out to determine opportunities and threats that might be faced by UD. Salacca Salak is a native Indonesian commodity which has good prospects for local and foreign markets. The main market segment of UD. Salacca exists on a domestic industrial scale. The potential for the development of processed zalacca is wide open and attracted many people. The need and demand for salak salak processed products. Salacca originates from the South Tapanuli region and outside the 
region. The allure of products that makes customers want to buy salak processed products is quality and diversification of products that are of good quality.

\section{b. Industrial Strength}

The strength of the salak processing industry can be seen from several components such as competitors, new players, substitute products and services, suppliers and other value chain actors, and stakeholders. Salak processed competitor UD. Salacca is a similar business unit that sells souvenirs made from zalacca in South Tapanuli, both long-standing and new players. Other competitors are similar processed products that have raw materials other than zalacca both locally and nationally. Other strengths of zalacca processing industry come from the stakeholders of zalacca suppliers / zalacca farmers whose zalacca production is always available, distributors, travel agents and souvenir merchants working together to make the business grow.

\section{c. Trends Key}

Key trends are important to analyze in order to support the changing business model of UD. Salacca is better. This key trend analysis can look ahead to technological trends, regulatory trends, societal and cultural trends, and socio-economic trends. The technology in zalacca processing is still a lot of manualization even though there is already a machine created to process zalacca. Utilization of appropriate technology that is appropriate to the needs in the production process can streamline time and cost. Government regulations or regulations, which are exhibitions held at home and abroad, can help companies to promote their products more broadly, and can increase business networks and relationships. Government assistance in the form of production machines adds to business efficiency. Community and cultural trends by getting used to buying souvenirs when visiting other regions create a huge business opportunity. Similarly, the lifestyle and eating patterns along with the higher level of income. People are more likely to live more practical lifestyles related to their limited time of rest, as well as the food patterns consumed tend to consume fast food.

\section{d. Macroeconomic Strength}

There are some countries that have experienced economic improvement but also some that have slowed. The drivers of economic growth are the manufacturing and trade sectors. The two sectors will be the drivers of world economic growth because market confidence has improved and also the recovery in prices of some commodities.

\section{SWOT Analysis in the Formulation of Strategies on Business Model Canvas}

SWOT identification on UD. Salacca is an amalgamation of information that has been obtained from internal analysis of $9 \mathrm{BMC}$ components and environmental analysis of the external (business) model as a means of obtaining external information. SWOT identification will explain the weaknesses, strengths, opportunities and threats faced by the company in each component of BMC. Internal parties, namely UD. Salacca which includes company management, human resources and capital resources owned. Furthermore, the external parties are the government, competitors, liaison, customers and suppliers. This SWOT identification is very important to do because the next steps in the formation of the new BMC will be derived from the information that has been summarized in this SWOT identification. After this SWOT identification is carried out, the next step is to analyze strategic issues on each component that might be developed into new ideas in the formulation of SWOT strategies. 
p-ISSN: $\underline{2685-7243}$

Table 1. Results of identification of SWOT 9 components of BMC UD. Salacca

\begin{tabular}{|c|c|c|c|c|c|}
\hline \multirow{2}{*}{ No } & \multirow{2}{*}{$\begin{array}{l}\text { BMC } \\
\text { Component }\end{array}$} & \multicolumn{4}{|c|}{ SWOT Identification } \\
\hline & & Strenght (S) & Weakness (W) & Opportunity $(\mathrm{O})$ & Threat $(\mathrm{T})$ \\
\hline \multirow[t]{2}{*}{1} & \multirow{2}{*}{$\begin{array}{l}\text { Customer } \\
\text { Segment } \\
\text { (CS) }\end{array}$} & $\begin{array}{l}\text { Customer segmentation already } \\
\text { exists }\end{array}$ & $\begin{array}{l}\text { There is no special service to } \\
\text { maintain customer loyalty }\end{array}$ & $\begin{array}{l}\text { The product has been favored } \\
\text { by domestic and foreign tourists }\end{array}$ & $\begin{array}{l}\text { Many competing products use } \\
\text { substitute raw materials }\end{array}$ \\
\hline & & strength of product positioning & $\begin{array}{l}\text { Some Products are not } \\
\text { always available }\end{array}$ & & \\
\hline \multirow{3}{*}{2} & \multirow{3}{*}{$\begin{array}{l}\text { Value } \\
\text { Propositions } \\
\text { (VP) }\end{array}$} & $\begin{array}{l}\text { Have internal and external quality } \\
\text { standards } \\
\text { (BPOM/PIRT/MUI/Disperindag }\end{array}$ & $\begin{array}{l}\text { Product supply has not been } \\
\text { fulfilled on a large scale }\end{array}$ & $\begin{array}{l}\text { UD Salacca processed products } \\
\text { can substitute honey from bees } \\
\text { and dates }\end{array}$ & $\begin{array}{l}\text { More salak farmers' yields are } \\
\text { sold to middlemen }\end{array}$ \\
\hline & & $\begin{array}{l}\text { Packaging attractive and modern } \\
\text { products }\end{array}$ & & & \\
\hline & & $\begin{array}{l}\text { The uniqueness of each product } \\
\text { diversification }\end{array}$ & & & \\
\hline \multirow[t]{2}{*}{3} & \multirow[t]{2}{*}{$\begin{array}{l}\text { Channels } \\
(\mathrm{CH})\end{array}$} & $\begin{array}{l}\text { Promotion has gone through } \\
\text { social media }\end{array}$ & $\begin{array}{l}\text { UD Salacca doesn't have a } \\
\text { web yet }\end{array}$ & $\begin{array}{l}\text { The government helps with } \\
\text { promotion through festivals } \\
\text { inside the city and outside the } \\
\text { city }\end{array}$ & $\begin{array}{l}\text { Misunderstandings with } \\
\text { distributors affect customer } \\
\text { segments }\end{array}$ \\
\hline & & $\begin{array}{l}\text { Already have a fixed product } \\
\text { distributor }\end{array}$ & & $\begin{array}{l}\text { Travel agent makes UD Salaaca } \\
\text { is a tourist stopover for } \\
\text { souvenirs }\end{array}$ & \\
\hline \multirow[b]{2}{*}{4} & \multirow{2}{*}{$\begin{array}{l}\text { Customer } \\
\text { Relationships } \\
\text { (CR) }\end{array}$} & Having loyal repeat customers & $\begin{array}{l}\text { Could not meet export } \\
\text { demand }\end{array}$ & $\begin{array}{l}\text { Already have a link to export } \\
\text { products }\end{array}$ & $\begin{array}{l}\text { Constrained in communicating } \\
\text { in a foreign language }\end{array}$ \\
\hline & & & & $\begin{array}{l}\text { Rasa khas produk disukai dan } \\
\text { diminati pelanggan lokal dan } \\
\text { asing }\end{array}$ & \\
\hline \multirow[b]{2}{*}{5} & \multirow{2}{*}{$\begin{array}{l}\text { Key } \\
\text { Resources } \\
(\mathrm{KR})\end{array}$} & 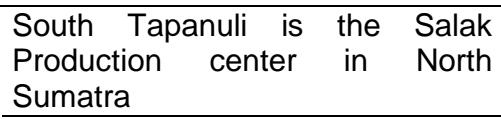 & $\begin{array}{l}\text { The production process still } \\
\text { uses simple technology }\end{array}$ & $\begin{array}{l}\text { There is counseling, training and } \\
\text { business assistance from the } \\
\text { Government }\end{array}$ & $\begin{array}{l}\text { Competing companies have } \\
\text { more sophisticated production } \\
\text { technology }\end{array}$ \\
\hline & & & Business capital is still limited & $\begin{array}{l}\text { The existence of production } \\
\text { machinery assistance from the } \\
\text { Government }\end{array}$ & \\
\hline
\end{tabular}

8| Hartati, J'; Tanjung,Y W; Widiasyih A S; Rasoki' T; Strategy In Development... 
p-ISSN: $2685-7243$

\begin{tabular}{|c|c|c|c|c|c|}
\hline \multirow{3}{*}{6} & \multirow{3}{*}{$\begin{array}{l}\text { Key Activity } \\
(\mathrm{KA})\end{array}$} & UD Salacca Strategic Location & $\begin{array}{l}\text { Some production activities still } \\
\text { rely on human resources } \\
\text { without mechanization }\end{array}$ & \multirow[t]{3}{*}{ Products easily enter the market } & \multirow[t]{2}{*}{$\begin{array}{l}\text { Appropriate technology is not } \\
\text { yet available to replace the } \\
\text { manual process in production } \\
\text { activities }\end{array}$} \\
\hline & & High Human Resource creativity & $\begin{array}{l}\text { There is no Standard } \\
\text { Operating Procedure (SOP) }\end{array}$ & & \\
\hline & & & $\begin{array}{l}\text { Does not have a special } \\
\text { laboratory for testing product } \\
\text { quality }\end{array}$ & & \\
\hline 7 & $\begin{array}{l}\text { Key Partners } \\
(\mathrm{KP})\end{array}$ & $\begin{array}{l}\text { UD Salacca has good relations } \\
\text { with suppliers, customers and } \\
\text { distributors }\end{array}$ & \begin{tabular}{lrr} 
There is no official & \multicolumn{1}{c}{ no } \\
cooperation & $\begin{array}{c}\text { contract } \\
\text { with }\end{array}$ \\
$\begin{array}{l}\text { suppliers, customers } \\
\text { distributors }\end{array}$ & & and \\
\end{tabular} & $\begin{array}{l}\text { Have the opportunity to } \\
\text { establish cooperation with the } \\
\text { Government and overseas } \\
\text { distributors }\end{array}$ & $\begin{array}{l}\text { Bad contact with customers, } \\
\text { distributors and customers can } \\
\text { affect the number of sales }\end{array}$ \\
\hline 8 & $\begin{array}{l}\text { Revenue } \\
\text { Streams } \\
\text { (RS) }\end{array}$ & $\begin{array}{l}\text { Sales profits increase on major } \\
\text { holidays }\end{array}$ & $\begin{array}{l}\text { On certain days the reception } \\
\text { is not optimal }\end{array}$ & $\begin{array}{l}\text { UD Salacca became a Price } \\
\text { Maker for similar products }\end{array}$ & Loyal customers \\
\hline 9 & $\begin{array}{l}\text { Cost } \\
\text { Structure } \\
\text { (CS) }\end{array}$ & $\begin{array}{l}\text { UD Salacca benefits } \\
\text { diversifying its products }\end{array}$ & $\begin{array}{l}\text { Production costs incur the } \\
\text { biggest cost }\end{array}$ & $\begin{array}{l}\text { The addition of technology and } \\
\text { human resources will increase } \\
\text { production }\end{array}$ & $\begin{array}{l}\text { Zalacca raw material prices } \\
\text { fluctuate }\end{array}$ \\
\hline
\end{tabular}

Details of the strategic issues that have been selected can be seen in Table 1 which is a means of strategy formulation in the Business Model Canvas. Not all elements of strengths, weaknesses, opportunities and threats that exist in SWOT identification are included in the SWOT analysis. Strategic issues are issues that if raised can have a major impact on business in the future. Strategic issues that have been selected in terms of strengths, opportunities, weaknesses, and threats are then analyzed. 
p-ISSN: $\underline{2685-7243}$

Table 2. Matrix of SWOT Analysis on UD. Salacca

\begin{tabular}{|c|c|c|}
\hline \multirow[b]{2}{*}{ Eksternal } & Strenght (S) & Weakness(W) \\
\hline & $\begin{array}{l}\text { Strong product positioning due to the } \\
\text { uniqueness of each product } \\
\text { diversification and attractive and } \\
\text { modern product packaging(VP, VP, } \\
\text { CS) } \\
\text { Have internal and external quality } \\
\text { standards } \\
\text { PIRT/MUI/Disperindag (VP) } \\
\text { South Tapanuli is the Salak Production } \\
\text { center in North Sumatra (KR) } \\
\text { Profits are increased on major holidays } \\
\text { by having diversified products, } \\
\text { permanent product distributors and } \\
\text { loyal customers (RS, C } \$, C H, C R)\end{array}$ & $\begin{array}{l}\text { Some products are not always } \\
\text { available, product supply has not been } \\
\text { fulfilled on a large scale, cannot meet } \\
\text { export demand (CS, VP, CR) } \\
\text { Business capital, technology and labor } \\
\text { are still limited (KR) } \\
\text { There is no official cooperation } \\
\text { contract with suppliers, customers and } \\
\text { distributors (KP) }\end{array}$ \\
\hline Opportunity (O) & SO Strategy & WO Strategy \\
\hline $\begin{array}{l}\text { Products are already in demand by domestic and foreign tourists } \\
\text { and have a link to export products (CS, CR) } \\
\text { The government helps promote through festivals in the city and } \\
\text { outside the city, making it easier for travel agents to make UD } \\
\text { Salaaca a stopover for tourists to buy souvenirs }(\mathrm{CH})\end{array}$ & $\begin{array}{l}\text { Increase consumer reach and } \\
\text { business scale }(\mathrm{S} 1, \mathrm{~S} 2, \mathrm{O} 1, \mathrm{O} 2) \\
\text { Increase production and customer } \\
\text { loyalty }(\mathrm{S} 3, \mathrm{~S} 4, \mathrm{O} 3)\end{array}$ & $\begin{array}{l}\text { Improvement of production facilities } \\
\text { and infrastructure (W1, W2, O3) } \\
\text { Increased cooperation contracts with } \\
\text { national and international partners } \\
(\mathrm{W} 3, \mathrm{O} 1)\end{array}$ \\
\hline
\end{tabular}

The existence of counseling, training and business assistance

assistance of production machinery from the Government so that

the addition of technology and human resources will increase

production (KR, C \$)

10 | Hartati, J'; Tanjung,Y W; Widiasyih A S; Rasoki' T; Strategy In Development... 
Many competing products that use substitution raw materials and Increase cooperation with raw material Increase capital, technology and labor more sophisticated production technology that result in non-loyal suppliers (S3, T2) (W1, W2, T1)

consumers (CS, KR, RS)

Improving services with consumers, Integrated partnership with farmers,

The price of zalacca raw materials fluctuates and is widely sold to

middlemen (C \$, VP)

$\begin{array}{ll}\text { partners }(\mathrm{S} 1, \mathrm{~T} 1, \mathrm{~T} 3) & \mathrm{T} 2)\end{array}$

Misunderstanding with distributors affects customer segments due

to constraints in communicating in foreign languages $(\mathrm{CH}, \mathrm{CR})$

\section{Information:}

CS $=$ Customer Segmens

$C R=$ Customer Relationship

$P V=$ Value Propositions

$\mathrm{CH}=$ Channels

$K A=$ Key Activities
$K R=$ Key Resources

$K P=$ Key Patners

$R S=$ Revenue Streams

$C S=$ Cost Structure 


\section{Application of the SWOT Strategy into the Business Model Canvas Component}

After the SWOT analysis produces a strategy, the next step is to apply the position of the strategy in the new BMC component. The following explanation is seen in table 3 :

Table 3. SWOT strategies in mapping the new Business Model Canvas

\begin{tabular}{l} 
SWOT Strategy \\
\cline { 2 - 6 } \\
\cline { 2 - 6 } SO = Increase consumer reach
\end{tabular}

From table 3 above it can be seen that some of the new BMC components that will be created are influenced by the strategies generated from the SWOT analysis both directly and indirectly. Direct changes occurred in the BMC component due to the implementation of the SWOT results strategy. While indirect changes occur in other components due to major changes in the BMC component due to the implementation of the SWOT strategy. In the SO strategy there is a direct influence on Customer Relationship that occurs due to the opportunity to establish relationships with a wider customer, thus encouraging an indirect influence on the components of Customer Segments, Channels, Key Patners, Revenue Streams and Cost Structure. In the implementation of SO1 strategy there is a direct influence on Key Activities in the form of increased production so that there is an indirect effect on Value Propositions, Channels, Customer Relationship, Revenue Streams and Cost Structure.

Then the WO strategy occurs a direct influence on Key Activities and Key Resources by increasing technology / production machinery so that production is greater so as to encourage an indirect effect on the Cost Structure component. The

12 | Hartati, J; Tanjung,Y W; Widiasyih A S; Rasoki' T; Strategy In Development... 
WO1 strategy has a direct effect on Key Patners by increasing collaboration with stakeholders so that it encourages an indirect influence on the components of Customer Segments, Value Propositions, Channels, Customer Relationships, Key Activities and Revenue Streams.

The implementation of the ST strategy has a direct effect on Key Patners by increasing raw materials to increase production so that it encourages an indirect effect on the Channels, Key Activities and Key Resources components. The ST1 Strategy for Customer Relationship by establishing relationships with customers and other stakeholders is better so that it encourages indirect influence on the components of Customer Segments, Value Propositions, Key Activities, Revenue Streams and Cost Structure.

The WT strategy has a direct influence on Key Resources with the increase in capital, labor and technology advances that are used so as to encourage an indirect effect on the Channels and Cost Structure components. The WT strategy has a direct effect on Key Patners so that it encourages an indirect effect on Key Activities, namely the location of UD. Salacca is strategic and has high human resource creativity

\section{CONCLUSIONS AND RECOMMENDATION}

\section{CONCLUSIONS}

Business model at UD. Salacca from the results of identification analysis of 9 components of the Business Model Canvass (BMC) can formulate a SWOT analysis: (1) SO strategy (2) OW Strategy, (3) ST Strategy and (4) TW Strategy. The SO strategy is to increase consumer reach and business scale and increase production and customer loyalty. The TW strategy is to improve production facilities and infrastructure and increase cooperation contracts with national and international partners. ST's strategy is to increase cooperation with suppliers of raw materials and improve services with consumers, distributors and merchant souvenirs. WaiYai's strategy to increase capital, technology and manpower and integrated partnerships with farmers, distributors and the government.

While the alternatives formulated by UD. Salacca based on BMC is influenced by strategies generated from SWOT analysis both directly and indirectly. Direct changes occurred in the BMC component due to the implementation of the SWOT results strategy. While indirect changes occur in other components due to major changes in the BMC component due to the implementation of the SWOT strategy.

\section{RECOMMENDATIONS}

UD. Salacca already has a strategy in increasing the business of salacca processed products into various types of food. However, UD. Salacca is also influenced by internal and external factors that can interfere with its prospects going forward. This needs to pay attention to internal factors that exist in UD. Salacca and external factors UD. Salacca is also the Government's policy in improving and the sustainability of MSMEs in Indonesia.

\section{ACKNOWLEDGMENTS}

This research is a research scheme in the competitive category of the National Research Beginner Lecturer (PDP) and funding from Kemenristek Dikti. 
p-ISSN: $\underline{2685-7243}$

\section{REFERENCES}

Amanulla AN, Faizah AA, Farah NH, Jamaludin I. 2015. Comparison of Business Models Canvas (BMC) Among the Three Consulting Companies. International Journal of Computer Science and Information Technology Research. 3 (2): 462-471.

Dinudin MN, Katsuri GN, Fedorova IJ, Dzusova SS, Namitulina AZ. 2015. The Innovation Model Canvas in the System of Effective Budgeting. Journal of Asian Social Science. 11 (7): 290-296.

Ostewalder A Pigneur Y., 2015. Business Model Generation. PT Elex Media Komputindo:Jakarta (ID).

Peratasari A, Dewanto W. 2013. Innovation Strategies for Global Competitive Advantages in Indonesian Cosmetics Ana Herbal Health Companies. Information Management and Business Review. 5 (8): 385-393.

Soekartawi. 2010. Agribusiness and Its Applications. Raja Grafindo Persada: Jakarta. 